\title{
Narration and historiography in McEwan's selected Novels
}

\author{
Maryam Sedaghat \\ English Department, Faculty of Foreign Languages, Isfahan University \\ Hezar Jarib Street,Isfahan, Iran \\ E-mail address: mary_white203@yahoo.com
}

Keywords: Narration; historiography; McEwan's

\begin{abstract}
As we saw in these three novels rewriting history may bring change of perspective, ideology and moral awakening for the reader. Linearity of history is challenged through depicting fragmented and multi-voiced personal histories. Historical traumas, although painful, bring an opportunity for revision and correction of our deeds. Without them human beings become complacent and immoral. For McEwan, writing about historical traumas is a solution to make historical traumas unforgettable and reminded to help us deal with our present situation which is vulnerable, violent and traumalogical. In these novels, self-reflection and self-transformation happens through writing about history.
\end{abstract}

\section{INTRODUCTION}

This paper analyzes three novels, Ian McEwan's novels, Atonement, Saturday and Black Dogs, as postmodernist historical novels. The study shows how these novels fit into the definition of histriographic metafiction, a concept introduced and developed by the postmodern critic Linda Hutcheon. It will show how the border between fiction and history is blurred and also how new literary works call into question the nature of history and historical writings. The attempt of the writer is to show how subjectivity and ideology intervene in the process of writing history and how different points of view create different accounts of a fixed single event. What postmodernism tries to prove is that history is a human construct and verbal artifact. The postmodernist view of history argues against conventional history writing, and it claims that historical narratives are shaped ideologically by the dominant discourses. The poststructuralist view entails the idea that there are plural meanings and truths as opposed to one meaning or one "Truth". It is a denial of the empirical concepts of history on which traditional historical novels before the introduction of postmodernist views were based.

The poststructuralist view entails the idea that there are plural meanings and truths as opposed to one meaning or one "Truth". It is a denial of the empirical concepts of history on which traditional historical novels before the introduction of postmodernist views were based.

Ian McEwan is a professional contemporary writer whose novels have attracted vast criticism. He writes both novel and short stories and his works differ in form and subject. From his early works these can be mentioned: short stories, First Love, Last Rites [1975] and In between the Sheets [1978] and seven novels_-The Cement Garden (1978), The Comfort of Strangers (1981), The Child in Time (1987), The Innocent (1989), Black Dogs (1992), Enduring Love (1997), and Amsterdam (1998)(Malcolm 3). Kiernan Ryan summarizes “the received wisdom” about McEwan's work as it was in 1994. As he states, 


\begin{abstract}
McEwan started out the seventies as a writer obsessed with the perverse, the grotesque, and the macabre. The secret of his appeal lay in his stylish morbidity, in the elegant detachment with which he chronicled acts of sexual abuse, sadistic torment and pure insanity. But towards the close of the decade his writing underwent a marked evolution as a result of his increasing involvement with feminism and the peace movement. His politically committed work for the cinema and television turned out to be a watershed in his career, from which his fiction emerged transformed. The claustrophobic menace of the stories and his first two novels gave way in the eighties to a more mature engagement with the wider world of history and society. The clammy feel of impending evil which fouled the atmosphere of his early fiction was dispelled by an emerging apprehension of the power of love and the possibility of redemption. (qtd. in Malcolm 4)
\end{abstract}

The novels selected in this study Atonement, Saturday and Black Dogs are among his later works which are concerned with history and the issues related to it. The various themes related to history such as lack of one single account of an event, the plurality of different points of view, the subjective nature of historical writings and history as verbal artifact are what Ian McEwan tries to depict in these three novels.

This is not just McEwan that tries to deal with history, its nature and the historical events in his novels. The inclusion of history in recent postmodern fictions is an issue some critics have discussed recently. Despite the fact that some critics like Jameson criticize the postmodernism for its ahistoricity, Hutcheon defends the inclusion of history in many postmodernist works. Hutcheon defines postmodernism "as fundamentally contradictory, resolutely historical and inescapably political" (A Poetics 4), so historicity is one of the main features of postmodernism. "Presence of past" is what she counts as one of the major characteristics of postmodernism. But return to past is not a simple return, but rather its aesthetic forms and its social formations are problematized by critical reflection and it has become more an ironic rethinking of history. This paper shows how history is challenged and at the same time regarded as an important part of human experience. The word construction implies self-consciousness in the process of creation of history and fiction. Therefore, the possibility of representing reality objectively is considered as a myth. The awareness of ideology as a political tool for manipulation and access to power changed the notion of historical objectivity. The reason for postmodern art to refer to the process of constructing history and fiction is that by depicting the process the fiction will reveal the interrelations of social, aesthetic, philosophical, and ideological constructs. In order to do so, postmodernist critics must acknowledge their own positions as an ideological one. Hutcheon maintains, "In fiction, it is self-reflexivity that works to make the paradoxes of postmodernism overt and even defining" (A Poetics 43). McEwan has shown how underlying systems of ideology and power relation shape the subject's consciousness and consequently the historians' taste and point of view.

\title{
2. NARRATION IN ATONEMENT
}

Atonement is divided into parts One, Two, and Three, and a short coda, "London 1999". Part one takes place on a day in 1935 and the main characters, their social positions, the relationship they bear to each other is explained through Briony's attempt to write a play and rehearse it for welcoming her brother Leon who is visiting from London with a friend, Paul Marshall. Her older sister Cecilia has returned from Cambridge and Robbie Turner, the son of the Tallis's cleaning lady is also there, doing cleaning and gardening. Besides they have three other guests, Pierrot, Jackson, and their fifteen-year-old sister Lola. Their mother, Mrs. Tallis is also introduced in the first part. However, the father of the family is absent. The whole novel is about the event that happens at the night that they have a dinner party to welcome Leon. Pierrot and Jackson are lost at night while the family is having their dinner and while they go to find them in darkness, Lola is raped by a stranger. The only person who claims that she has seen the scene accuses Robbie for this crime and Robbie goes to jail. The other parts are fragmented accounts of Robbie's experiences in war, Cecilia's life 
as a nurse and Briony's guilt-ridden service as a nurse helping soldiers wounded in war. Although the plot is simple, the techniques, both modernist and postmodernist, have resulted in creating a work which not only does not follow realism, but also helps exploring different styles and structures. McEwan uses and at the same time subverts the conventions of realism and modernism. $\mathrm{He}$ is a follower of modernist convictions, but at the same time, moves away from them and changes the context and content whenever he wants to clarify that modernist conviction no longer fit the complicated world of postmodernity. The importance of the influence of key stylistic techniques of modernism on McEwan's writing is clearly evident in his works. The influence of Virginia Woolf in particular is marked - McEwan even goes so far as to refer to her writing in Atonement, both in the process of narration through artistic strategies and techniques (Richard Robinson 473-75).

By taking the idea of possibility of representation as its theme, the novel plays with historiography and fiction and the place of form in representing the historical realities. Therefore, the narrative taking a distance from an historical text is manifest in its violation of the reality revealed in the final chapter of the novel. It is a historical investigation and interrogation of real. The themes of the novel are historical exploration and the possibility of representing the events as they actually have happened.

Reality is challenged, not in a sense that reality did not exist, but that it is a construct of the mind of the writer/historiographer and also it depends on the observer's point of view. The novel attempts to thematize the fact that there is always a gap between the linguistic representation of reality and reality itself. Reality is questioned and challenged in different ways from the events and incidents in the story to the juxtaposition of the real with the fictive. The ideas of writing and manipulation of history are focused on throughout the narrative on the level of both form of the novel and subject matter. In this novel, the past is still a living force that is always open to new readings and interpretations. This calls into question the authenticity of historical accounts, including the grand narratives of war.

Atonement questions two issues: first, the possibility of representing truth in narrative and two, the possibility of objectivity in narration of past events, especially grand historical events. Those narratives, including history, can be faked due to special interests and/or ideologies of the narrator because historical representation accordingly requires creation and interpretation; it is not an objective recounting as historiography and literary realism credit. Briony exposes the fictionality of the referent. The text does refer to a referent or a set of referents that may not exist anymore. Nevertheless, referentiality is constructed and created in the writing-reading process; thus problematisation of representation lies in her fictive construction of realities, that is, in metafiction. She shatters the illusion of objectivity and transparency, for it unmasks the process of creation and offers the work as an artifact not a book based on truth and reality.

The novel demystifies the fictional relation between the novel and its referents to the reader by exposing the strategies and techniques employed by the writer. For example representation of herself as a character and narrating herself through an omniscient point of view deceives the reader into believing that the text must be narrated by McEwan not Briony. The technique of fiction within fiction mainly as a postmodernist technique is used to reveal the constructed nature of all writings. It emphasizes the fact that fiction is created by a writer and thus, it is a virtual created world. Unlike literary realism which aims at presenting a monolithic single authoritative voice which narrates the events from one consciousness's point of view, this novel provides a set of contradictory voices, meanings and consciousness, each interpreting the world from a different point of view. Nick Bently refers to the fact that every character, every consciousness, interprets the events from his/her point of view, the novel, then, shows how romanticized accounts of real events can lead to dangerous misinterpretations : 
Robbie had made a great show of removing his boots which weren't dirty at all, and then, as an afterthought, took his socks off as well, and tiptoed with comic exaggeration across the wet floor. Everything he did was designed to distance her. He was play-acting the cleaning lady's son come to the big house on an errand. (Atonement 27)

Robbie on the other hand sees the occasion differently:

That was the day he had first noticed his awkwardness in her presence. Kneeling to remove his work shoes by the front door, he had become aware of the state of his socks - holed at toe and heel and, for all he knew, odorous - and on impulse had removed them. What an idiot he had felt, padding behind her across the hall and entering the library barefoot. (Atonement 84 qtd. in Bently)

The main aim of postmodernist works on the subject of history is to show the processes in which ideology of any kind grants meaning to historical events and to our historical and literary knowledge and experiences. This narrative defies and mocks the possibility of accessing to the truth of the past events. So they exert self-reflective techniques to allude to the constructed nature of all narratives. Thus, any external event is open to different interpretations and readings. Briony both as the observer and as the writer cannot be completely reliable. This unreliability is depicted through narrating the same events from different points of view in order to respect the postmodernist celebration of plurality of visions and perceptions. The third person omniscient point of view is imitated to confirm reliability; it, however, is questioned by a shift to the first person in last chapter to make the reader aware of the fictionality and unreality of what she/he has read. The last part of the novel (coda) shocks the reader and emphasizes the belief that reality can be easily manipulated whether it is historical reality or mundane reality. The reality is that the story of Robbie and Cecilia is a tragedy but it has been turned to comedy, a happy ending story in which the lovers live happily ever after. The reason of the manipulation is the author's guilt. As Brian Finney argues:

By making the protagonist and narrator a writer McEwan has situated the act of artistic composition in the context of national history. Ostensibly a novel concerned with the relationships between fact and fiction, the novel's use of metafiction draws attention to the way fictional writing cannot be isolated from the wider concerns of history and politics. In the first place, when novelists force us to understand the constructed nature of their characters by commenting on their own act of creation, they invite us simultaneously to reflect on the way subjectivity is similarly constructed by ideological means in the non-fictional world we inhabit. (91)

Also Briony's dementia, can add to this unreliability:

I have vascular dementia, the doctor told me, and there was some comfort to be had. There's the slowness of the undoing, which he must have mentioned a dozen times. Also, it's not as bad as Alzheimer's, with its mood swings and aggression. If I'm lucky, it might turn out to be somewhat benign. I might not be unhappy-just a dim old biddy in a chair, knowing nothing, expecting nothing. I had asked him to be frank, so I could not complain. Now he was hurrying me out. There were twelve people in his waiting room wanting their turn. In summary, as he helped me into my coat, he gave me the route map: loss of memory, short- and long-term, the disappearance of single words - simple nouns might be the first to go-then language itself, along with balance, and soon after, all motor control, and finally the autonomous nervous system. Bon voyage!(Atonement 256)

The purpose of the writer is to awaken his readers; those who so readily believe the written words and challenge and subvert the idea of historical truth. In fact, truth and the possibility of seeking it in narratives is challenged in a way that convinces the reader that reality and truth are inaccessible 
and only can be presented partly in narrative. The novel's use of postmodernist techniques such as intertexuality, self-reflexivity, parody, shifting perspectives, discontinuity are applied for the purpose of emphasizing the constructed nature of all narratives. From the beginning of Atonement it is clear that Briony, at the age of thirteen, does not separate fiction and truth. The tension between the real and fictive is presented throughout the novel, and is for instance manifested as Briony's desire to be both playwright and the lead role (Arabella) in her play. It is an example of Briony's inability to separate the imagined from the real: she seems to believe that she has the same power over real people as over her invented characters - just as in her novel later, Atonement, she is the same manipulative writer who reflected her desires and ideas in her literary work. The difference between Arabella and Atonement is that in the latter the reader is unaware of the truth of the events that happened in reality. The techniques which she uses hide realities and manipulate them but in Arabella she used a genre which was too transparent. Atonement is puzzle-like; it makes the reader arrange all the pieces to understand the reality, however, even this arrangement does not usher the reader to the right truth. McEwan wants to emphasize the capacities of fiction. Fiction can tell lies.

The fictional world has preceded reality and even has the power to change and manipulate it. This manipulative nature of narrators is depicted in Briony's manipulative nature as a writer, both in her childhood and in her adult life. Briony is the novelist, the heroine, the villain and the historian in the novel. She takes roles and gives roles to manipulate the world in a way she wishes. She has the power to put order on disorder of the world and her fictional world seems to win over the reality. For her, a world which is different from the real world seems more interesting. She is the magician in her role as the author. She can change a good person into a bad character (like Robbie) or a monster (like her adolescent self) into the angel of the story. She can draw sympathy from the reader for the villain of the story (herself) and arrange the events in a sequence which makes her actions plausible and justified.

The real and fictional intermingle and no one can separate them due the reality of fictional world and the fictional nature of the real. In other words, the ontological instability that exists in this novel confuses the reader in a way that finding out the truth (the truth of what happened that night at which Lora was raped, the truth of what happened between Cecilia and Robbie and every single event presented in the novel) seems impossible. How is the reader going to understand the truth when the novel is the constructed artifact of one of the characters and at the same time the real author McEwan? The novel uses both epistemological and ontological skepticism to subvert the certainty of the existence of truth. In Atonement there are two fictional worlds created, one by Briony in her adult life and one by the real author, Ian McEwan. Thus, the world created by McEwan is two steps away from reality. The reader cannot be certain of the existence of the characters and the created world, despite some external historical truths that are alluded to. Representing the reality is done by language, and language seems the most unreliable way due to its contradictory nature. The world made by Briony is a world of fiction intermingled with some external historical realities like war. We know that Briony has a manipulative nature and cannot be trusted, so the whole novel is read with a sense of suspicion of her purpose.

Briony is first introduced as a writer before anything else. The first presentation of her character is her role as a playwright and amateur writer who has imaginary worlds in which a hero, a villain and a victim exist.

THE PLAY - for which Briony had designed the posters, programs and tickets, constructed the sales booth out of a folding screen tipped on its side, and lined the collection box in red crêpe paper - was written by her in a two-day tempest of composition, causing her to miss a breakfast and a lunch. (Atonement 3 )

Her wish to put order on the world around her is the career of a writer who shapes her characters' lives, motivations and roles. Her main characteristic is that she cannot make a difference between the external world, which is a complicated real world with its infinite complexities and her. From the beginning, writing seems inevitable, a show off activity which helps her to gain attention 
and manipulate others, "Briony knew he had a point. This was precisely why she loved plays, or hers a least; everyone would adore her" (Atonement 9 ).

"Her play was not for her cousins, it was for her brother, to celebrate his return, provoke his admiration and guide him away from his careless succession of girlfriends"(Atonement 4).

Through the novel Briony shifts her literary practices from different literary genres and styles. First Romance is absorbing genre to her, because Romance represents a simplistic, black and white world in which the good is always rewarded and the bad is always punished and this is exactly the way Briony sees the world. In her immature and naïve mind life is about pure love, good nature, second chances and the possibility of reunion with one's lover. In her mind she identifies herself with the heroin of her story:

She said no, but she meant yes. Of course she was taking the part of Arabella. What she was objecting to was Lola's "because." She was not playing Arabella because she wrote the play, she was taking the part because no other possibility had crossed her mind, because that was how Leon was to see her, because she was Arabella. (Atonement 11)

The idea that Briony writes to express her own thoughts and wishes in disguise, makes narrative a forum for expression of subjective desires and thoughts. This is true about all narratives even historical narratives which claim of being objective. Briony, who is an adolescent and naïve, cannot understand that Romance is too simplistic to represent the truths of the real world. Briony likes Romance probably because she wants to see the good rewarded and the bad punished; in other words she sees the ideal not the real. Because of her idealism she likes to see reality in a way she wants and this is the reason for her fatal mistake. In her claim for seeing Robbie as the rapist, she prefers her imagination over reality. Interestingly, the novel proves her assumptions wrong: the love of Cecilia and Robbie is almost never fulfilled, the villain gets away with his crime (the real rapist is never recognized and punished) the innocent man is punished (Robbie is punished for what he has never done). Integration of Romance seems ironic because McEwan wants to emphasize the fact that in modern world, values and structures have reversed and we need more complicated, nonrealist, non-linear narratives to convey themes and meaning. The novel seems an attempt to reveal the fact that imagination can undermine reality. Briony's imagination mixes reality and fictive and other people have to pay for her mistake.

The relationship between narrative and history lies in her attempt to write a history of a family and two lovers, Robbie and Cecilia. In writing this family history, her imagination plays a great role. The novel cannot be written in linear realist genre because the adult Briony as a professional writer is aware of the power of narration in making the illusion of reality; besides, she knows well that reality is multidimensional, so she tries to reveal the reality of an event from different points of view. There is always another version for the same event; as the knowledge of the effect of point of view in representation is what historian should consider in recording history. History cannot be represented in linear narrative which submits easily to one single truth. The novel provides us with a sense of how history should be represented, whether past reality can indeed be accessed at all, or if the multiplicity of viewpoints and contingent representations suggest that no true representation of reality is possible, or even desirable. This multiplicity of reality is suggested through revealing different consciousness about one single event. Every character has his/her interpretation and way of perception.

If we assume that the family history is a small model for history of a nation. The historical events like World War II have been integrated into a domestic story. In fact, the novel mixes domestic and historical to highlight the role of history in its characters' lives. The gaps of history are filled by the historian who has his/her own motivations and ideologies. As White argues, "Since no given set or sequence of real events is intrinsically 'tragic,' 'comic,' or 'farcical,' but can be constructed as such only by the imposition of the structure of a given story-type on the event, it is the choice of the story-type" (The Question of Narrative 20). As it was mentioned before the story 
of Cecilia and Robbie's love is tragic but it is represented otherwise, a happy-ending story with the possibility of living happily ever after. The story type is chosen by Briony, the narrator, the recorder and the writer of what really happened, she is also a possible narrator of a historical event, like war. Actually, Briony's motivation for representing the miseries of Robbie in war is a kind of atonement and apology for her wrong testimony against him. She feels a need to represent Robbie's consciousness as a representative of a generation whose names, lives and miseries have been lost in the statistics of war. Robbie needs to be singled out, and his miseries and pain are meant to be shown because he is a victim of history. Thus, Briony becomes a historian of a destructive war. She needs to write a history, her own history, Robbie's history and her country's history. She writes family history, and a larger history, the history of England in a particular time. Brian Finny has argued a relation between Robbie's position which falls and the West's position and maintains that "Robbie is typical of the collective delusion at that time with his fantasies of a future life spent as a family doctor and spare time reader. The West is about to be hurled into a war that will usher in a radically different postmodern era to which this narrative, completed in 1999, belongs" (10).

Her motivation is getting rid of her guilt for the crime he committed. The reader cannot be so sure of the reality of what happened to the characters in reality because of unreliability of Briony's narration. She wrote plays for getting her brother's attention and she changed the end of the story as she liked "I've always liked to make a tidy finish" ( Atonement 353) which indicates the fact that her love for order has not been diminished even in her old age. She likes happy ending, as in writing her romance she preferred compensation and a way out. Her manipulation of reality, indeed inevitability of historical representation to exclude, omit, erase, and select important elements of history, reflecting the contemporary rise of relativist historiography is seen in Briony's atonement.

Can we accept the Dunkirk part as a piece of history or a piece of fiction? The reader of Atonement reads a piece of fiction, which is at the same time a piece of history; because it is about the effects war can have on the lives of individuals. The historical time and place are based on reality and at the same time the techniques for presenting this are fictional. There is no line between fiction and history because they are intermingled in a way that they are inseparable. There are always fictional elements in historiography. The difference between official history and Briony's novel is that official history is about general and total and her fiction is about particular cases in history. Robbie is a particular case in history which makes the experiences of a soldier in war tangible for the reader.

\section{ALLUSION TO LITERATURE IN SATURDAY}

In this novel the allusions to literature and poetry is thematized in different parts of the novel. Literature and science confront each other to prove the significant role they both play in human life. The novel questions the role of science in saving human beings in contemporary time. Literature and humanities can also save us from our present condition which is a violent, tensed and miserable condition. Henry, the protagonist a man of science is in confrontation with his daughter Daisy a poetess trying to convince his father that literature is great thinks that "perhaps he's becoming, in this one respect at least, like Darwin in later years who found Shakespeare dull to the point of nausea. Perowne is counting on Daisy to refine his sensibilities" (Saturday 58). A neuro-surgeon's utilitarian and scientific mind rejects unreal and imaginary in favor of real and tangible.

His free time is always fragmented not only by errands, and family obligations, and sports, but by the restlessness that comes with these weekly islands of freedom. He doesn't want to spend his days off lying or even sitting down, nor does he really want to be a spectator of other lives, of imaginary lives, even though these past hours he's put in an unusual number of minutes gazing from the bedroom window, and it interests him less to have the world reinvented. He wants it explained. The times are strange enough, why make things up? (Saturday 66) 
Matthew Arnold's view that literature should go shoulder by shoulder of science in a developed society seems quite relevant to the theme of the novel. Actually he did not agree that the development in natural sciences will lead to progress in human history. In his view, humanities and especially literature would help man to know himself and the world better. As Deshmukh states, literature "provides us with knowledge about our nature, the world and the better ways for a better life. A work of art blends great truth with aesthetic form and promotes disinterested contemplation which transcends an individual from the temporal to the universal" (33). He also argues about the role literature especially poetry plays in enriching culture. The purpose of literature is enhancement of life and the propagation of human values; however, this is not done through any systematic theory or method of politics or religion. For Arnold the change must be done through literature. Arnold's article about the importance of literature and belles lettres was a response to Huxley's defense of science against humanities in his lecture, "Literature and Science", which later was turned into an article.

In his lecture, Arnold criticized Huxley for rejecting belles lettres as one of the ways of progress in human society and regarding it unimportant and slight. Huxley was a man of science as Perowne is. The way Henry sees the world is rational and scientific, an inherited legacy from the age of Enlightenment which has led to the contemporary age with its complex problems.

\begin{abstract}
He tries to see it, or feel it, in historical terms, this moment in the last decades of the petroleum age, when a nineteenth-century device is brought to final perfection in the early years of the twenty-first; when the unprecedented wealth of masses at serious play in the unforgiving modern city makes for a sight that no previous age can have imagined. Ordinary people! Rivers of light! He wants to make himself see it as Newton might, or his contemporaries, Boyle, Hooke, Wren, Willis those clever, curious men of the English enlightenment who for a few years held in their minds nearly all the world's science. Surely, they would be awed. (Saturday 168)
\end{abstract}

The concept of progress is taken under survey to analyze its real meaning in twenty first century. Progress, as it meant in Enlightenment age, is challenged and seems to need revision. Henry needs to change his views about progress, other human beings and literature. The answer to critical search for truth has not been only science. Henry's doubtful and skeptical views are signs of the unsteady position of science. In Saturday, fiction does not have appeal for the protagonist because it is not based on reality and scientific evidence. Fiction seems useless in the world of rationality, technology and science; however, at the end of the story literature has the power to save and to humanize both Baxter and Henry. The inability to understanding fiction is the inability to get out of one's self to sympathize with other suffering human beings. At the end of the day, it is literature that is a savior, a solution and the best way for communication. Literature changes human beings as it changes Baxter and Henry, and makes them get out of their selves and imagine themselves in other people's place. This is the first step towards humanity. This is the mutual interdependence of both scientific knowledge and humanistic knowledge for keeping anarchy in check. It is Perowne's superior scientific knowledge that allows him to trick Baxter during the car incident and escape, trick him once again in the London family home, and which quite conveniently saves Baxter's life in the operation theatre to keep bad conscience at bay. But it is Daisy's superior grasp on "the best that is known and thought in the world" in literature, founded on her grandfather's teachings and encouragement, which crucially transforms Baxter (Eckstein 8).

The idea of taking responsibility for other human beings, everywhere in this world apart from race, ethnicity or nationality is a far-fetched dream. The question of possibility of such world, without violence and tension between individuals in it, a happy world with no war and terrorism seems impossibility, but our love for other human beings and seeing them as fellow human beings who have the same hopes and suffering as we do, is the first step to cleansing the world of terrorism. 
He lets it engulf him. There are these rare moments when musicians together touch something sweeter than they've ever found in rehearsals or performance, beyond the merely collaborative or technically proficient, when their expression becomes as easy and graceful as friendship or love. This is when they give us a glimpse of what we might be, of our best selves, and of an impossible world in which you give everything you have to others, but lose nothing of yourself. Out in the real world there exist detailed plans, visionary projects for peaceable realms, all conflicts resolved, happiness for everyone for ever--mirages for which people are prepared to die and kill? (Saturday 171)

McEwan sees the solution for ending terrorism and violence both in national or international level is not in ignoring other counties rather our daily inter-personal relationship. Humanity and brotherhood will be brought back to the globalized world if we are ready to understand the other's (and other countries) ideology, logic, way of thinking and try to connect them through irrational way of love. So the answer to the horrors of living in a world characterized by violence, suffering and uncertainty is love, unconditional love for other human beings apart from their social status, race, ethnicity and gender. However, there is an ominous barrier and that's pride and selfishness hidden in ideological basis of western democracies and that is liberal-humanism and his promise of fulfillment of human capacities and gaining human dignity.

"living after such events as $9 / 11$ and the prospect of a potential world disaster such as the Iraq war, as well as the constant threat more locally of violent crime, means that to live 'in a city' in this new century makes it impossible simply to "obliterate ... the public domain" (Saturday108). As Saturday makes clear, the attempt to isolate oneself from the world, whether on a global or a personal level, is not only irresponsible, but also it is dangerous. The change of attitude and world view of Perowne at the end of the day reveals itself in the way of his looking.

As Eskstein states, "My point will ultimately be that the consolations McEwan has to offer for a world in perceived crisis are the dubious certainties of a distinctly Victorian liberal humanist moral universe" (2). The revival of ethical issues by postmodern writers is due to the failure of scientism and rationality even after 9/11. The collapse of the twin towers proved the inability of Western democracies to understand other developing nations, their ideologies, their demands and even their suffering.

The novel suggests that the change must happen. We should find ways to diminish violence at individual, national or international level. Perowne's defensive overreaction to the violent other and his inability to imagine the other's perspective causes the violent attack to his house. Perowne's house represents western nations; the attack of $9 / 11$ is because of a lack in knowledge and experience of confronting the other nations. The failure of the west to see the other (nations) as an alter ego, human beings like themselves and ignoring the responsibility they have towards these less fortunate and underdeveloped countries. "9/11 provoked a new feeling of being vulnerably connected to people, places and experiences" (Isherwood 1). McEwan offers us an ethical solution for the current violent situation of the globe after $9 / 11$.

\section{BLACK DOGS AND HISTORY}

As the poet Craig Raine remarks about Black Dogs, it is "a novel whose formal perfection was so subtle that most critics failed to notice" (qtd. in Malcolm 133). The whole novel of Black Dogs seems an attempt for recording a memory which seems to have complicated aspects. At first, the act of writing a memoir seems an easy task that can be done voluntarily by Jeremy, an orphan who investigates the past of his parents in law. However, narration of one single event becomes difficult, because Jeremy finds contradiction in different accounts of the event (the encounter of June with two black dogs). Time shifts, contradictions and the mixture of different genres, play with the idea of the possibility of an objective narration. Reality seems evasive, contradictory and ungraspable. 
Black Dogs is also about inexplicability of certain actions and events and expressing this inexplicability in form and content. There are numerous allusions to historical events and date, first in Berlin chapter Jeremy and Bernard go to Berlin to watch the fall of Berlin wall "The point is that German unity is an inevitability. The Russians will rattle their sabres, the French will wave their arms, the British will um and ah" (Black Dogs 72), and the chapter set in Majdanek, in 1989 and the references to the holocaust and other historical events "a residual truth was sufficient to transform Majdanek for me in an instant from a monument, an honourable civic defiance of oblivion, to a disease of imagination" (Black Dogs 110). Jeremy reflects on historical catastrophes and the victims of these catastrophes "I saw a hobnail boot beside a baby shoe whose nursery lamb still showed through the dust. Life turned to tat. The extravagant numerical scale, the easy-to-say numbers - tens and hundreds of thousands, millions -denied the imagination its proper sympathies" (Black Dogs 110). Elsewhere the post-war years are described in St Maurice de Navacelles, which is exactly related to the time June encountered the two black dogs. All these allusions to historical dates and places imply the novel's concern with history and the issues related to it.

The novel deserves the label historiographic metafiction, because it simultaneously questions this literary trend and its underlying assumptions. As it was mentioned before historiographic metafiction is about 'secret histories' that displaces the official history and also the feature of selfreferentiality that is seen in the novel. The process of writing history is depicted in Jeremy's attempt to find out the 'truth' about the relationship of June and Bernard. In the process of searching this truth many contradictions appear because there is no easy access to truth. Different points of views (June's point of view, Bernard's point of view, Jeremy's point of view) create different versions of a single reality due to different perception of people from external realities. As Hutcheon suggested in historiographic metafiction "we find deliberately manipulative narrators; and we have no one single perspective but myriad voices, often not completely localizable in the textual universe" ( $A$ Poetics 160).

What Jeremy does is to prove is 'personal and historical knowledge as perspective'. Of course Jeremy tries to represent the whole truth; however, the contradictions and difference in narration of the characters make this aim impossible. The point of the author is that if finding truth about a simple single event like confrontation of a woman with two black dogs and the possibility of writing a biography is so difficult, then the writing about historical events that have changed the course of millions of lives may be with many difficulties. Taking sides seems very difficult and Jeremy with his position as a biographer is accompanied by his skepticism which is mentioned in some parts of the novel: "that's a significant discovery for a woman. Or it was in my day. Perhaps it was a fateful discovery too, a disastrous one. I'm not so sure now I should have stood alone. The rest is harder to tell, especially to a skeptic like yourself" (Black Dogs 58).

His skepticism and indecision in his quest for searching truth is an indication of the failure of postmodernist quest for truth, especially historical truth. What happened to June with its historical overtones, the reality of existence of the two black dogs, the accuracy of a memory all of them are in a halo of uncertainty. Uncertainty is a postmodernist feature. The recorder of history also is not sure of the truth of his writings and the novel suggests the necessity of reassessing the truth represented in different ways. The novel fits historiographic metafiction title, because it mixes historical situations with personal experiences of those historical situations. Jeremy's memoir has self-reflexive features in which the process of collecting data leads to contradictions. His intention for keeping a memory among thousands of memories of a particular time in history and his attempt to give an objective account of what really happened to June is a parodic imitation of conventional historiography. The references to 'factual' historical events, places and dates, the difficulty of representing a simple event, encountering with two black dogs, is emphasized. When the writer and the reader cannot trust a simple event like what happened to June, the whole recorded histories of a distant past are looked at skeptically. 
Jeremy's role as a memoir writer is similar to a historian who wants to gather his material for a chronicle. He wants to depict a life story which seems to be the story of what happened in the world during a specific time. Instead of a linear chronicle in which the sequences of events follow chronological time, his memoir is a personal history of historical events in a fragmented and disrupted way. This selection of non-linear and multilayered form is a depiction of non-linear nature of history. The present disrupts the past and the past interrupts present and the reader is forced to connect these events to each other to grasp a picture of what really happened. There is a lack of a coherent plot in a way that the reader cannot tell what the story is about. Instead of a coherent plot, an event which is the effect of historical horrors on a young lady and her confrontation with evil as the legacy of a heinous war is repeated in different parts of the novel. The idea of writing a memoir comes to Jeremy as a possibility for answering some questions, "Slowly, far too slowly as it turned out, there emerged from my meandering conversations with June the possibility of a memoir I would write. The idea embarrassed the rest of family. I was suspected of wanting to threaten a difficult truce by turning up forgotten quarrels" (Black Dogs 32).

This attempt at writing the past becomes problematic, unsettling and trouble-making. Others object to this quest, because it may bring old and settled issue to the surface. The past is seen as a force influencing the present and future, from which there is no escape. It is through tracing the past that some present problems are reconsidered and understood. Jeremy's attempt at writing a family memoir, which turns out to be very difficult, implies that every search for truth is problematic. He also acts as a historian seeking truth in fragmented historical events. This emphasizes the subjectivity of the historical process and foregrounds the inevitable selection processes of historiography. As we see in novel, June's account of an event is different from Bernard's. Jeremy is at a loss as to which perspective is closer to the truth. Each of the characters refutes and reconstructs the other's version, our assumptions, like Jeremy's, are undermined, and so is the moral weight we cannot help but attach to each version. Each version seems plausible and close to reality. Objective perception seems impossible as the history is so. In historical writings, the different accounts of a single event make the objective outlook impossible. Shaping power of the historian cannot be denied. The relation of the past to present is symbolized in the picture of June and Bernard in their honeymoon. By looking at this picture, Jeremy wants to trace the past, and thus his fascination with their past begins with this picture. "The photograph now hangs in the kitchen of our house in the Languedoc. I have often studied it, usually when alone. Jenny, my wife, June's daughter, suspects my predatory nature and is irritated by my fascination with her parents" (Black Dogs 26). June asks, "Why should I expect millions of strangers with conflicting interests to get along when I couldn't make a simple society with the father of my children, the man I've loved and remained married to?" (Black Dogs 53).

Also in his visits with June, Jeremy tries to see the difference between June in the present and June posed for the photo. His investigation of the past is helping him to see the present in better terms. By studying the past he gains a vision which helps him to analyze the events around him better than before. The study of the past brings maturation of the mind and gives us a better understanding of present and it also gives us a vision without which we are lost in a world of ideas and wrong practices. So the novel is a kind of self-scrutiny for its characters especially Jeremy. This maturation completes in the climax of the story: Hitting an oppressive father who uses violence without any reason to do so.

The manipulation of historical facts is also seen in this part. McEwan's idea about the past as something unreliable and destined to be manipulated is depicted in form of the way history is represented in statistics and official documents. In this section, the truthfulness of official histories is called into questions. The official history has the ability to misrepresent, to give false information, to establish lies instead of truth. The truth is there but one can misrepresent and eliminate a part of truth. 


\begin{abstract}
We stopped outside the main entrance to read a sign which announced that so many hundreds of thousands of Poles, Lithuanians, Russians, French, British and Americans had died here.it was very quiet. There was no one in sight. I felt a momentary reluctance to enter. Jenny's whisper startled me. 'No mention of Jews. see? it still goes on. And it's official. The she added, more to herself,' the black dogs. (Black Dogs 110).
\end{abstract}

The main concern of the novel seems to be history and memory and the ways they can be recorded and saved. Biography and memoir are the ways of preserving history from amnesia and misrepresentation. Writing seems as the best and only solution for representing history. However, this writing can be faulty and incomplete.

\title{
5. ATONEMENT, SATURDAY AND BLACK DOGS AND HISTORICAL CONDITIONS
}

Temporal placement evoked in the narratives is crucial for the understanding of the narratives especially in these three novels which are placed in historical time. Atonement spans the period from the summer of 1935, cf. Robbie is sentenced in 1935 (Atonement 208), over the war to 1999, referred in the last chapter (Atonement 353), so it covers 64 years of the life of the characters especially Briony: "What a strange time this has been. Today, on the morning of my seventyseventh birthday" (Atonement 353). The choice of the years has not been accidental, rather it has been chosen carefully, because it sets exactly in a historically significant period in England and in the world. It is one year before the Spanish Civil War and rise of fascism in Europe. The lives of the characters become more complicated with the emergence of war. Saturday sets in February the $15^{\text {th }}$ 2003 which is related to 9/11 antiwar protest in London. Black Dogs time span is a long time from 1946 to 1989 with the allusions the novel make to historical time and events. The usage of the real historical dates adds authenticity to these works and strengthens the theme of these novels that is, the effect of historical conditions on personal lives of the individuals. Living in a specific historical time highly affects the lives of the characters and engages them directly and indirectly in historical events. In Atonement, the characters' lives especially Robbie's and Cecilia's are influenced by historical events happening around them.

Robbie becomes a soldier involuntarily and fights in the war without any personal reason and motivation. He is a victim of historical circumstances over which he has no control. His life would be different if he was born in a different age or different historical time. In Atonement, historical circumstances are overwhelming. History is a deconstructive and demolishing force and in comparison to its force, the individuals' lives seem trivial and unimportant. In this view of history, the human beings are the victims of historical conditions. The objectivity of the historical conditions and the indifference to the fates of the subjects are emphasized. In this case, the personal capacities of the individual are limited in a way that he cannot struggle for a better condition, because history is such forceful that the individual's will is trivial and insignificant in confrontation with it.

In Atonement it is too late to change the course of history and no one, both from upper class or middle class, is not immune from the destructive hand of history. Time is an all-important element in the conflict of contending social forces and in determining individual's life. The individual enters as an effective factor in the total process of historical determination only when all the other forces in history are temporarily equalized.

In Saturday, history is not presented as a predetermined victimizing force; rather it seems changeable, flexible and apt to be transformed by individuals' actions and decisions. The individuals can take part in constructing human conditions. Although in Saturday there is no escape from taking responsibility in constructing historical and social conditions in which we live, history seems highly dependent on individual's actions, ideas and determination for changing it. The conditions of the world have changed in a way that one's determination and decision for changing the conditions can stop the historical disasters like war (like the impending war on Iraq). Perowne's actions can change the happening of war although he is unaware of his power in making decisions 
for history. The setting of the novel indicates that the individuals are located in certain historical time and their actions highly influence what later becomes a part of history. The idea is that although war in inevitable one should not get passive and docile, Perowne is described as a "docile citizen" (Saturday 180). He thinks with himself that what is going to be done is done even without his participation in anything. He tries to be indifferent and inactive:

Does he think he's contributing something, watching news programmes, or lying on his back on the sofa on Sunday afternoons, reading more opinion columns of ungrounded certainties, more long articles about what really lies behind this or that development, or about what is most surely going to happen next, predictions forgotten as soon as they are read, well before events disprove them? For or against the war on terror, or the war in Iraq; for the termination of an odious tyrant and his crime family, for the ultimate weapons inspection, the opening of the torture prisons, locating the mass graves, the chance of liberty and prosperity, and a warning to other despots; or against the bombing of civilians. (Saturday 180)

The contemporary world, with the social and political forces in it, needs social mobility and taking action. The novel condemns (albeit indirectly) the complacency and passivity of both the masses and the intellectuals and encourages them to change their indifferent attitude to the social and political events happening around them; also it depicts the view that history is not a predetermined force. The role played by individuals can be decisive, and it is perhaps the last decisive link in the chain of causality in history. In fact, under certain circumstances, the 'subjective factor' can become the most important factor in history along with other factors. As Plekhanov states, "men make history, and, therefore, the activities of individuals cannot help being important in history" (9). The role of the individual from a mere on-looker should change into an activist who cares for the oppressed and the repressed. The social context is also determining in taking action in the course of history. Individual's character is a 'factor' in social development only where, when, and to the extent that social relations permit it to be. It is true that there are limits to individual actions; however, taking action is inevitable in a world in which everything and everyone are integrated in a chain of cause and effect. In a world that a stranger may become like one's brother. Henry understands this sense of responsibility at the end of the novel.

He's responsible, after all; twenty hours ago he drove across a road officially closed to traffic, and set in train a sequence of events. Or it could be weakness after a certain age, when the remaining years first take on their finite aspect, and you begin to feel for yourself the first chill, you watch a dying man with a closer, more brotherly interest. (Saturday 278)

In a larger scope, we all share lives in this planet and every individual's life are dependent on the others' lives. The codependency makes the world need mutual understanding for making a better civilization, something that is not achieved yet and the upcoming war on Iraq is evidence for the troubled relationship between the West and the Middle East.

In Black Dogs there is a mixture of both of these views. On the one hand, the subject becomes a victim of history (the allusion to W.W.II, concentration camps and the victims of historical violence) and on the other hand, human's actions have the power to change history. Indifference to the fate of other human beings has been condemned. There is a sense of fear of evil forces in human nature which makes history violent and bloody. The root of evil is traced back to our inner forces, and historical disasters seem to be only some revelations of these forces. The solution for deterring these historical disasters to happen is love and care for other human beings.

\section{CONCLUSION}

As we saw in these three novels rewriting history may bring change of perspective, ideology and moral awakening for the reader. Linearity of history is challenged through depicting 
fragmented and multi-voiced personal histories. Historical traumas, although painful, bring an opportunity for revision and correction of our deeds. Without them human beings become complacent and immoral. For McEwan, writing about historical traumas is a solution to make historical traumas unforgettable and reminded to help us deal with our present situation which is vulnerable, violent and traumalogical. In these novels, self-reflection and self-transformation happens through writing about history. In order to have a comprehensive knowledge of the world which is vulnerable to violence is felt and represented. James Berger states, "We can understand a present situation only in relation to some past event; yet, because this past event has, through its overwhelming violence and horror, obliterated itself, it can only be encountered by means of its effects in the present" (565).

\section{Primary Sources}

McEwan, Ian. Atonement. New York: Anchor, 2003.

---. Saturday. London: Jonathan Cape, 2005.

---. Black Dogs. London: Vintage, 1998.

\section{References}

[1] Arnold, Matthew. "Dover Beach". The Norton Anthology of English Literature. Ed. M. H. Abrams et al. New York: Norton, (1986): 1383-84.

[2] Bentley, Nick. Contemporary British Fiction. Edinburgh: Edinburgh University Press, 2008.

[3] Berger, James. "Trauma without Disability, Disability without Trauma: A Disciplinary Divide" Jac.24.3 (2004)

[4] Deshmukh, Ajay. "Mathew Arnold and 'Liberal Humanism'. International Refemed Research Journal.3.32 (September 2011)

[5] Eckstein, Lars. "Saturday on Dover Beach: Ian McEwan, Mathew Arnold, and Post-9/11 Melancholia. Hard Times, (2012)

[6] English, James F. Contemporary British Fiction. Oxford: Blackwell Publishing, 2006.

[7] Finney, Brian. English Fiction since 1984: Narrating a Nation. New York: Palgrave

[8] Macmillan, 2006.

[9] Hutcheon, Linda.A Poetics of Postmodernism. London: Routledge, 1988.

[10] ---. The Politics of Postmodernism. New York: Routledge, 1989.

[11] Jameson, Fredrich. Postmodernism, or, the Cultural Logic of Late Capitalism. Durham: Duke University Press, 1991.

[12] Malcolm, David. Understanding McEwan. South Carolina: University of South Carolina's Press, 2002.

[13] White, Hayden. Metahistory: The Historical Imagination in Nineteenth-Century Europe. Baltimore, Md: Johns Hopkins University Press, 1973.

[14] ---." The Historical Text as Literary Artifact" in Canary and Kozicki .Hopkins University Press, (1978): 41-62 
[15] ---. "The Value of Narrativity in the Representation of Reality." Critical Inquiry, (1980): 7, 1: $5-27$.

[16] ---."The Question of Narrative in Contemporary Historical Theory", History and Theory,1:133

[17] ---. Figural Realism. Studies in the Mimesis Effect. Baltimore and London: The Johns Hopkins University Press, 1999.

[18] ---. The Content of the Form: Narrative Discourse and Historical Representation. Baltimore and London: The Johns Hopkins University Press, 1987.

[19] ---. The Historical Imagination in Nineteenth Century Europe. Baltimore and London: The John Hopkins University Press, 1973.

[20] Williams, John. "Fact in Fiction: Problems for the Historical Novelist." Denver Quarterly 7, 4(1973) 1-12. 